\title{
Adrenomedullin and its receptor, calcitonin receptor-like receptor, are aberrantly expressed in women with idiopathic menorrhagia
}

\author{
CHUNFANG HA ${ }^{1,2}$, ANNELI STAVREUS-EVERS ${ }^{3}$, BRITT-MARIE LANDGREN ${ }^{3}$, \\ MIRIAM MINTS ${ }^{3}$ and MARGARET C.P. REES ${ }^{4}$
}

\author{
${ }^{1}$ Ninxia Medical College, Department of Obstetrics and Gynecology, Ningxia, P.R. China; ${ }^{2}$ Department of Clinical Science, \\ Intervention and Technology, Karolinska Institutet, Stockholm; ${ }^{3}$ Department of Women's and Children's Health, \\ Uppsala University, Uppsala, Sweden; ${ }^{4}$ Nuffield Department of Obstetrics and Gynaecology, \\ University of Oxford, Oxford, UK
}

Received September 19, 2008; Accepted October 27, 2008

DOI: $10.3892 / \mathrm{mmr}+00000053$

\begin{abstract}
The human endometrium undergoes a unique process of benign angiogenesis under the control of ovarian steroids during reproductive life. Aberrant angiogenesis has been implicated in idiopathic menorrhagia, a common gynaecological complaint. One of the key factors involved in endometrial angiogenesis is adrenomedullin (AM), a multifunctional 52-amino acid peptide. AM mediates the activities of endometrial angiogenesis via calcitonin receptor-like receptor (CLR). The objective of the present study was to compare the endometrial expression of AM and CRL in women with and without idiopathic menorrhagia. Endometrial biopsies were obtained from 9 women with menorrhagia ( $\geq 80 \mathrm{ml}$ per menstruation) and 12 women with normal blood loss ( $<80 \mathrm{ml}$ per menstruation). Protein and mRNA expression levels of AM and CLR were determined using immunohistochemistry and real-time PCR. Compared to the controls, patients with menorrhagia exhibited low immunostaining intensity of AM, while high CLR staining was observed in the epithelium $(\mathrm{p}<0.05)$. No difference in mRNA expression was observed between the groups. These data suggest that an imbalance in the AM/CLR system might alter endometrial angiogenesis in menorrhagia.
\end{abstract}

\section{Introduction}

The human endometrium undergoes a unique process of benign angiogenesis under the control of ovarian steroids during reproductive life. One of the key factors involved in endometrial angiogenesis is adrenomedullin (AM), a multifunctional

Correspondence to: Dr Anneli Stavreus-Evers, Department of Women's and Children's Health, Uppsala University Hospital, Uppsala University, SE-751 85 Uppsala, Sweden

E-mail: anneli.stavreus-evers@kbh.uu.se

Key words: menorrhagia, adrenomedullin, calcitonin receptor like receptor, endometrium 52-amino acid peptide originally isolated from a human phaeochromocytoma $(1,2)$. AM belongs to the calcitonin family, which comprises six known members: calcitonin, amylin, two calcitonin-gene related peptides (CGRP- $\alpha$ and CGRP- $\beta$ ), AM and intermedin $(3,4)$. Originally identified as a hypotensive peptide, AM was subsequently shown to be an angiogenic factor $(1,5)$. Since then, it has become apparent that it has a wide range of other biological actions, including the regulation of cell growth and differentiation.

AM mediates its activities via heterodimeric receptors composed of calcitonin receptor-like receptor (CLR) and one of the three receptor activity-modifying proteins (RAMPs) $(3,6)$. RAMPs alter the affinity of the CLR receptor to the related peptides. Under normal conditions, the CLR/RAMP1 heterodimer shows greater affinity for CGRP. However, when associated with RAMP2 or RAMP3 it shows greater affinity for $\operatorname{AM}(3,6)$.

Menorrhagia is a common gynaecological condition - the main presenting complaint in women referred to gynecologists - and accounts for two-thirds of all hysterectomies. Between 1994 and 1999, one in every nine women aged 35-45 years had a hysterectomy in the US (7). Thus, menorrhagia is an important healthcare issue. In approximately $50 \%$ of cases, no pathology is found at hysterectomy. Aberrant angiogenesis has therefore been implicated $(8,9)$.

The aim of this study was to examine AM and CLR expression as well as vascular density in the endometrium of women with menorrhagia compared to healthy controls.

\section{Materials and methods}

Study population. Endometrial biopsies were obtained from healthy volunteers ( $n=12$, mean age 34 years) and from women with menorrhagia (menstrual blood loss $\geq 80 \mathrm{ml}$ per menstruation, $n=9$, mean age 42 years). All the women had regular menstrual cycles of 25-32 days. None had used hormonal or intrauterine contraception for at least three months prior to the study.

Menstrual blood loss was assessed with pictorial blood loss assessment charts (PBAC) (10). Clinical examination, transvaginal ultrasound and hysteroscopy revealed no pathology. Platelet count, activated prothrombin thromboplastin 
Table I. Adrenomedullin staining intensity and number of stained vessels in the endometrium of healthy women ( $\mathrm{n}=12)$ and of women with menorrhagia $(n=9)$.

\begin{tabular}{lcccc}
\hline Group & Luminal epithelium & Glandular epithelium & Stoma & Vessels \\
\hline Control & $2.0(0.0-3.0)$ & $2.0(1.0-2.5)$ & $2.0(1.0-2.5)$ & $1.0(0.5-1.5)$ \\
Menorrhagia & $2.0(0.5-2.5)$ & $1.5(1.0-2.5)$ & $0.5(0.0-1.0)^{\mathrm{a}}$ & $1.0(0.5-2.0)$ \\
\hline
\end{tabular}

Median value and range is shown; $\mathrm{p}<0.05$ considered statistically different.

time, INR, bleeding time and von Willebrand factor were all normal.

Informed consent was obtained from all participants. The Ethics Committee of the Karolinska Institute approved the study.

Endometrial biopsies. Biopsies were obtained using a Pipelle sampler (Pipelle Laboratoire C.C.D., Paris, France), and were performed during the luteal phase on the anterior wall of the uterine cavity on day following the surge of luteinizing hormone $(\mathrm{LH})+6$ to $\mathrm{LH}+8$. Participants identified the day of the LH surge by testing their morning urine. All biopsies were fixed in $4 \%$ formaldehyde for a maximum of $24 \mathrm{~h}$, then stored in $70 \%$ ethanol until embedding. An additional three biopsies from each group were frozen in liquid nitrogen for RT-PCR. All biopsies used in the study had a normal histology compatible with the phase of the cycle.

Immunohistochemistry. Paraffin-embedded biopsies were sectioned, dewaxed in Bioclear (Bio-Optica, Milan, Italy) and rehydrated by decreasing ethanol concentrations and washing in phosphate-buffered saline (PBS). Endogenous peroxidases were blocked using 3\% hydrogen peroxide in methanol for $10 \mathrm{~min}$, and slides were then washed in PBS. Thereafter, the samples were blocked using $1.5 \%$ normal goat serum for $\mathrm{AM}$ and CLR and horse serum for CD31, then incubated for 30 min. Rabbit monoclonal IgG against human AM (Peninsula Laboratories Inc., San Carlos, CA, USA) and rabbit immune serum against CLR were used as the primary antibodies (11), respectively diluted to $1: 500$ and 1:1500. Human myometrium was used as the positive control for ADM. Normal rabbit serum was used as the negative control for CLR and AM. The slides were incubated at $4^{\circ} \mathrm{C}$ in a humidified chamber overnight.

The sections were subsequently washed in PBS with $0.01 \%$ Tween-20. Biotinylated goat anti-rabbit IgG was used as a secondary antibody. The slides were incubated for 45 min with the secondary antibody, followed by incubation for $45 \mathrm{~min}$ in a freshly-prepared solution of peroxidase avidin biotin complex (Vectastain ABC Elite, Vector Laboratories, Burlingame, CA, USA). Thereafter, the slides were washed and stained using 3,3-diaminobbenzidine in $\mathrm{H}_{2} \mathrm{O}_{2}$ (DAB-kit, Vector Laboratories for AM and AP kit for CLR), then counterstained with haematoxylin and dehydrated before mounting with Pertex (Histolab, Gothenburg, Sweden).

Evaluation of immunohistochemistry. Two independent viewers, blinded to the identity of the slides, assessed each sample. Staining intensity was evaluated semi-quantitatively using the following grading system: 0 , no staining; + , faint staining; ++ , moderate staining; +++ , strong staining.

To quantify the number of vessels in the endometrium, the vessels in six randomly selected fields of views were counted in each slide at a magnification of $x 400$. The average number of vessels in each view was then calculated.

Data were expressed as the mean \pm range and statistically evaluated using the Mann-Whitney rank sum test. A difference of $\mathrm{p}<0.05$ was considered significant.

RNA and cDNA preparation. Frozen endometrial tissue was homogenized in lysis buffer then extracted using the Qiagen RNA mini kit (Invitrogen, Stockholm, Sweden) according to the manufacturer's instructions. The concentration and purity of the RNA were measured using Quantity-One (Bio-Rad, Clinical Diagnostic, Sundbyberg, Sweden).

Total RNA $(600 \mu \mathrm{g})$ was reverse transcribed using Invitrogen's SuperScript according to the manufacturer's instructions. The samples were then stored at $-20^{\circ} \mathrm{C}$ until PCR.

Quantitative-PCR. Real-time PCR was performed using an ABI PRISM 7700 sequence detector (Applied Biosystems, Foster City, CA USA). cDNA $(8 \mu \mathrm{g})$ combined with $5 \mu \mathrm{l}$ SYBR Green mixture, $1 \mu 1$ each of the forward and reverse primers and $2 \mu 1$ of water was subjected to quantitative-PCR using a SYBR green assay. The expression of each gene was normalized against GAPDH using a standard curve constructed from the cDNA dilution. The cDNA was then heated to $50^{\circ} \mathrm{C}$ for $2 \mathrm{~min}$ and denatured at $95^{\circ} \mathrm{C}$ for $10 \mathrm{~min}$. The template was amplified over 45 cycles of $60 \mathrm{sec}$ melted at $95^{\circ} \mathrm{C}$ and $60 \mathrm{sec}$ at $62^{\circ} \mathrm{C}$ for annealing and extension. Primer sequences were as follows: AM, sense 5'-AAG AAG TGG AAT AAG TGG GCT-3', antisense 5'-TGG CTT AGA AGA CAC CAG AGT-3'; CLR, sense 5'-CTC CTC TAC ATT ATC CAT GG-3', antisense 5'-CCT CCT CTG CAA TCT TTC C-3'; GAPDH, sense 5'-GAA GGT GAA GGT CGG AGT CAA C-3', antisense 5'-CAG AGT TAA AAG CAG CCC TGG-3'. Fluorescence data was acquired by measurement every $7 \mathrm{sec}$ and presented as a plot of fluorescence intensity versus cycle number.

Data analysis for quantitative-PCR. All samples were run in duplicate. Data were imported and analysed using ABI PRISM 7000 Software version (Applied Biosystems, Foster City, CA, USA) and normalised against GAPDH. 


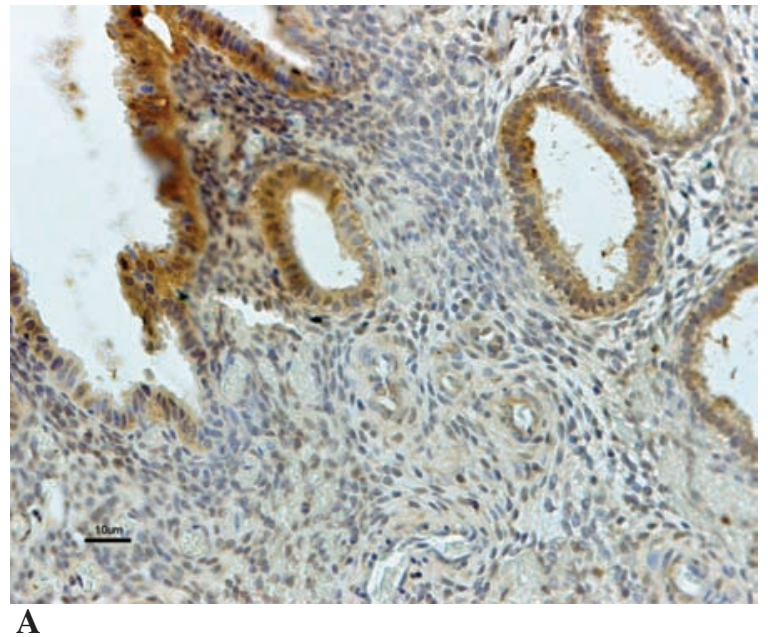

A
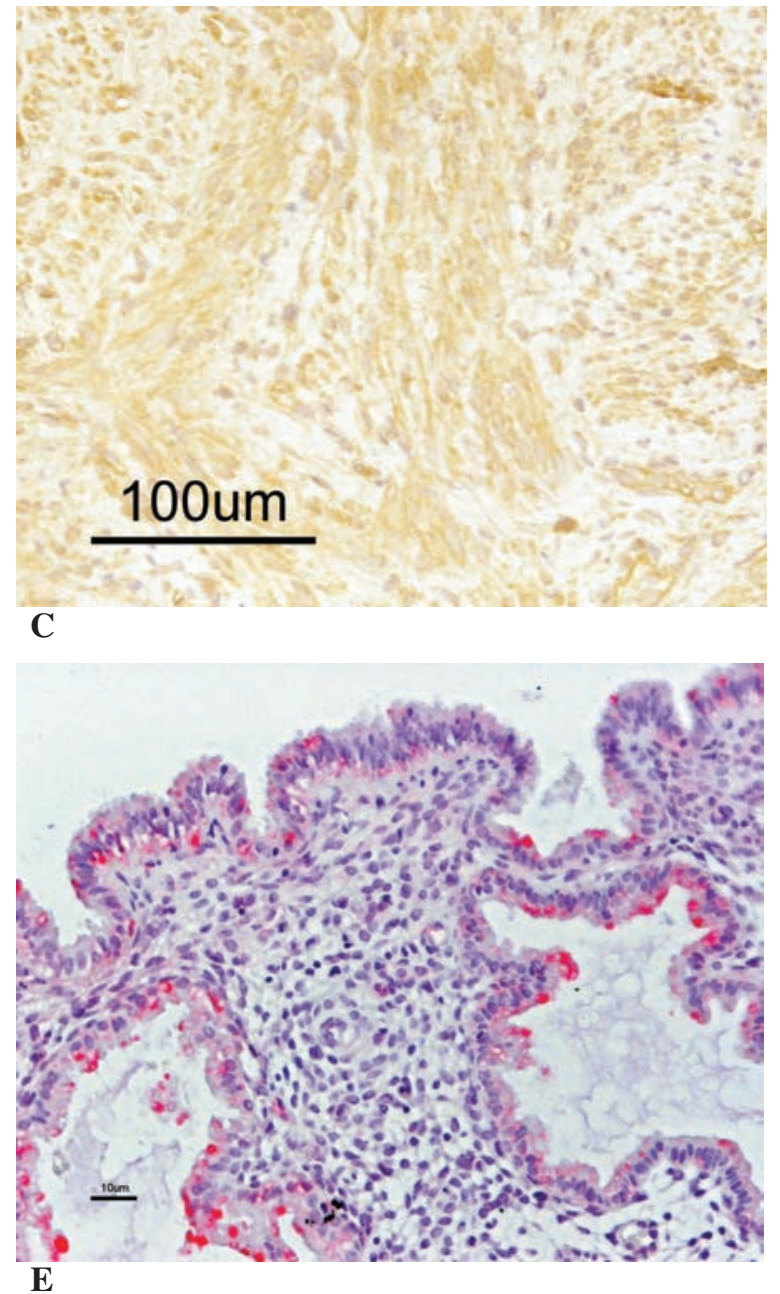

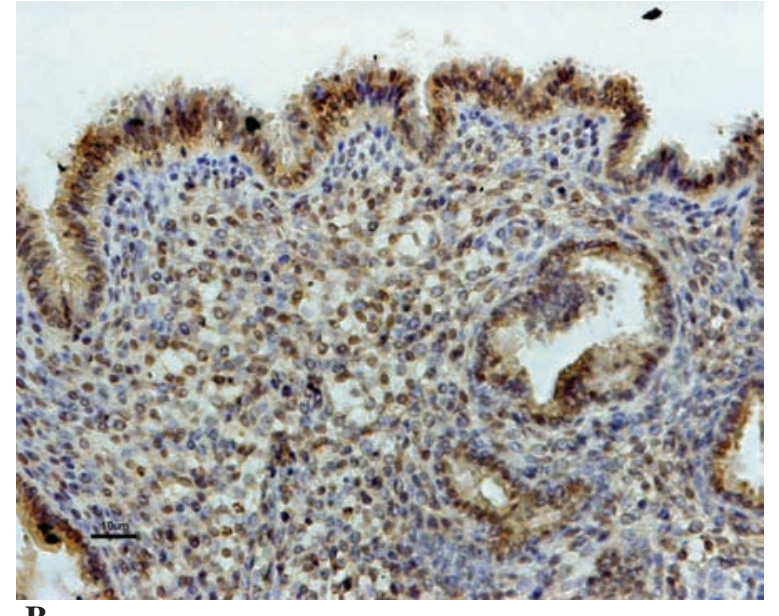

B
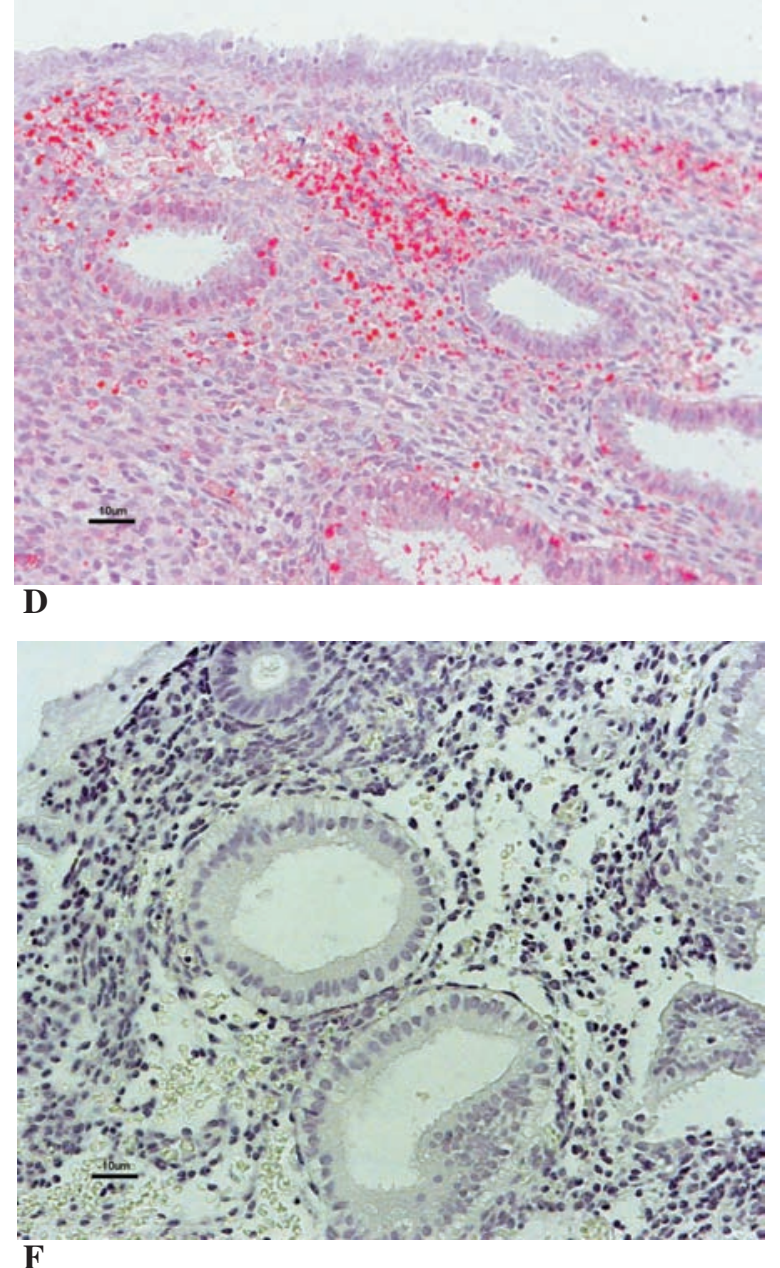

Figure 1. Distribution of adenomedullin (AM) and calcitonin receptor-like receptor (CLR) in the endometrium. (A) Immunostaining for AM in a control sample; (B) immunostaining for AM in a menorrhagia sample; (C) positive control for AM; (D) immunostaining for CLR in a control sample; (E) immunostaining for CLR in a menorrhagia sample; (F) negative control for AM and CLR.

\section{Results}

Immunohistochemical expression of AM in the endometrium. Immunostaining of AM was seen in all endometrial cell types (Fig. 1). There was a lower staining intensity in the stroma in tissue obtained from women with menorrhagia compared to the controls (Table I).
Immunohistochemical expression of calcitonin receptor-like receptor in the endometrium. Immunostaining of CLR was seen in all endometrial cell types (Fig. 1). Immunostaining in the endometrium of the menorrhagia group was more intense in the luminal epithelium $(\mathrm{p}=0.002)$ and glandular epithelium $(\mathrm{p}=0.0059)$ compared to that observed in the controls (Table II). 
Table II. Calcitonin receptor-like receptor staining intensity and number of stained vessels in the endometrium of healthy fertile women $(n=12)$ and of women with menorrhagia $(n=9)$.

\begin{tabular}{lccccc}
\hline Group & Luminal epithelium & Glandular epithelium & Stroma & Vessels & No. of stained vessels \\
\hline Control & $0.5(0.0-2.0)$ & $1.0(0.0-2.5)$ & $0.5(0.0-2.0)$ & $1.6(0.6-2.4)$ & $7.5(1.0-16.0)$ \\
Menorrhagia & $1.5(0.5-2.5)^{\mathrm{a}}$ & $2.0(1.5-3.0)^{\mathrm{a}}$ & $1.0(0.0-1.5)$ & $1.9(1.6-2.2)$ & $7.5(3.4-12.0)$ \\
\hline
\end{tabular}

Median value and range is shown; $\mathrm{p}<0.05$ considered statistically different.

Table III. Relative expression of adenomedullin and calcitonin receptor-like receptor mRNA in the endometrium of healthy fertile women $(n=3)$ and of women with menorrhagia $(n=3)$.

\begin{tabular}{lcc}
\hline Group & AM & CLR \\
\hline Control & $1.04(3.61-0.41)$ & $1.07(0.20-1.08)$ \\
Menorrhagia & $3.34(0.21-1.33)$ & $0-66(0.60-0.66)$ \\
\hline
\end{tabular}

Median value and range is shown.

Adrenomedullin and calcitonin receptor-like receptor $m R N A$ expression in the endometrium. There were no differences in mRNA expression between the two groups (Table III).

\section{Discussion}

$\mathrm{AM}$ is a multifunctional peptide hormone that plays a significant role in vasodilatation and angiogenesis $(12,13)$. The human endometrium is a mucosa served by a microvascular blood supply that involves benign angiogenesis, which is under the control of ovarian steroids throughout reproductive life $(14,15)$. In agreement with previous studies, we found AM and CLR to be expressed in all endometrial cell types (2).

Aberrant angiogenesis has been implicated in menorrhagia $(5,8)$. As has been previously reported, we found vessel density to be similar in the endometrium of patients with idiopathic menorrhagia compared to that of the controls (16). The expression of AM was weaker in the stroma of the endometrium of menorrhagia patients than in that of the controls, although staining in the vessels was similar. These results suggest that paracrine interaction between endothelial and stromal cells may be critical to normal endometrial endothelial function. While AM is a vasodilator, most models indicate that it also stabilises the endothelial barrier (17-20). Thus, decreased stromal expression of AM could result in increased vascular permeability, resulting in increased blood and fluid loss (21).

CLR expression was increased in the epithelial cells of the endometrium of women with menorrhagia. This increased expression may lead to heightened sensitivity to AM and to the production of prostaglandins, agents known to be involved in menstrual bleeding $(22,23)$ and endometrial growth $(24)$.
Immunostaining revealed some differences in protein expression compared to mRNA levels in tissue homogenates. This is most likely due to the fact that fewer samples were used for real-time PCR than for immunohistochemistry. Individual variation between samples could also contribute to this occurrence.

In conclusion, our data indicate that the AM/CLR system is critical to normal endometrial function, and that imbalances in this system might be involved in the pathogenesis of idiopathic menorrhagia.

\section{Acknowledgements}

The authors thank Dr Leonid Nikitenko (University College, London, UK) for provision of the CLR antibody. We would also like to thank Dr David Poyner (Aston University, Birmingham, UK) for his helpful comments. This study was supported by the Swedish Research Council (2005-7293), the Magn Bergvalls Foundation, the Swedish Medical Society, the Åke Wibergs Foundation, Uppsala University and the Karolinska Institutet.

\section{References}

1. Kitamura K, Kangawa K, Kawamoto M, Ichiki Y, Nakamura S, Matsuo $\mathrm{H}$ and Eto T: Adrenomedullin: a novel hypotensive peptide isolated from human pheochromocytoma. Biochem Biophys Res Commun 192: 553-560, 1993.

2. Nikitenko LL, MacKenzie IZ, Rees MC and Bicknell R: Adrenomedullin is an autocrine regulator of endothelial growth in human endometrium. Mol Hum Reprod 6: 811-819, 2000.

3. Poyner DR, Sexton PM, Marshall I, et al: International Union of Pharmacology. XXXII. The mammalian calcitonin gene-related peptides, adrenomedullin, amylin, and calcitonin receptors. Pharmacol Rev 54: 233-246, 2002.

4. Roh J, Chang CL, Bhalla A, Klein C and Hsu SY: Intermedin is a calcitonin/calcitonin gene-related peptide family peptide acting through the calcitonin receptor-like receptor/receptor activity-modifying protein receptor complexes. J Biol Chem 279: 7264-7274, 2004.

5. Nikitenko LL, Smith DM, Hague S, Wilson CR, Bicknell R and Rees MC: Adrenomedullin and the microvasculature. Trends Pharmacol Sci 23: 101-103, 2002.

6. McLatchie LM, Fraser NJ, Main MJ, Wise A, Brown J, Thompson N, Solari R, Lee MG and Foord SM: RAMPs regulate the transport and ligand specificity of the calcitonin-receptorlike receptor. Nature 393: 333-339, 1998.

7. Keshavarz HHS, Burney AK and Marchbanks PA: Hysterectomy Surveillance, United States 1994-1999. MMWR Surveill Summ 51: 1-8, 2002.

8. Oehler MK and Rees MC: Menorrhagia: an update. Acta Obstet Gynecol Scand 82: 405-422, 2003.

9. Jabbour HN and Sales KJ: Prostaglandin receptor signalling and function in human endometrial pathology. Trends Endocrinol Metab 15: 398-404, 2004. 
10. Deeny M and Davis JA: Assessment of menstrual blood loss in women referred for endometrial ablation. Eur J Obstet Gynecol Reprod Biol 57: 179-180, 1994.

11. Nikitenko LL, Blucher N, Fox SB, Bicknell R, Smith DM and Rees MC: Adrenomedullin and CGRP interact with endogenous calcitonin-receptor-like receptor in endothelial cells and induce its desensitisation by different mechanisms. J Cell Sci 119: 910-922, 2006.

12. Fernandez-Sauze S, Delfino C, Mabrouk K, et al: Effects of adrenomedullin on endothelial cells in the multistep process of angiogenesis: involvement of CRLR/RAMP2 and CRLR/RAMP3 receptors. Int J Cancer 108: 797-804, 2004.

13. Shindo T, Kurihara Y, Nishimatsu H, et al: Vascular abnormalities and elevated blood pressure in mice lacking adrenomedullin gene. Circulation 104: 1964-1971, 2001.

14. Folkman J: Angiogenesis in cancer, vascular, rheumatoid and other disease. Nat Med 1: 27-31, 1995

15. Girling JE and Rogers PA: Recent advances in endometrial angiogenesis research. Angiogenesis 8: 89-99, 2005.

16. Mints M, Hultenby K, Zetterberg E, Blomgren B, Falconer C, Rogers R and Palmblad J: Wall discontinuities and increased expression of vascular endothelial growth factor-A and vascular endothelial growth factor receptors 1 and 2 in endometrial blood vessels of women with menorrhagia. Fertil Steril 88: 691-697, 2007.
17. Hocke AC, Temmesfeld-Wollbrueck B, Schmeck B, et al: Perturbation of endothelial junction proteins by Staphylococcus aureus alpha-toxin: inhibition of endothelial gap formation by adrenomedullin. Histochem Cell Biol 126: 305-316, 2006.

18. Tam C and Brain SD: The assessment of vasoactive properties of CGRP and adrenomedullin in the microvasculature: a study using in vivo and in vitro assays in the mouse. $\mathrm{J}$ Mol Neurosci 22: 117-124, 2004.

19. Temmesfeld-Wollbruck B, Brell B, David I, et al: Adrenomedullin reduces vascular hyperpermeability and improves survival in rat septic shock. Intensive Care Med 33: 703-710, 2007.

20. Miyashita K, Itoh H, Arai H, Suganami T, et al: The neuroprotective and vasculo-neuro-regenerative roles of adrenomedullin in ischemic brain and its therapeutic potential. Endocrinology 147: 1642-1653, 2006

21. Reid PC: Assessment of menorrhagia by total menstrual fluid loss. J Obstet Gynaecol 26: 438-441, 2006.

22. Jabbour HN, Kelly RW, Fraser HM and Critchley HO: Endocrine regulation of menstruation. Endocr Rev 27: 17-46, 2006.

23. Jougasaki M, Aarhus LL, Heublein DM, Sandberg SM and Burnett JC Jr: Role of prostaglandins and renal nerves in the renal actions of adrenomedullin. Am J Physiol 272: F260-F266, 1997.

24. Mennel HD, Hallier-Neelsen M, Hagner S and Benes L: Two novel cell specific receptor proteins, CRLR and CD 117 in human glial tumors. Clin Neuropathol 25: 107-114, 2006. 
